\title{
Komunikasi Antarpribadi Ibu dan Anak dalam Membangun Rasa Percaya Diri
}

\author{
Sarah Cecil, H.H.Daniel Tamburian \\ Sarah.915150172@stu.untar.ac.id,danielt@fikom.untar.ac.id
}

Fakultas Ilmu Komunikasi Universitas Tarumanagara

\begin{abstract}
Communication is the most important thing in life. Communication is an interaction between one person and one or more people. This study will focus on interpersonal communication that occurs between mother and child in building self-confidence. The character of a child is determined by a mother, because of the closeness of a mother while at home. Child time with mother at home is much more than father. Therefore, the nature of a child is completely passed on by the mother. A mother's love and concern greatly affect a child's self-confidence. The mother communicates with her child so that the child feels happy and comfortable. This research uses a qualitative approach. Data collection techniques by means of semistructured interviews with mothers and children who are high school students. This research shows that the closeness between the child and the mother is not determined by gender. Mothers have a crucial role in making children appear confident. You do this by reminding children to be themselves, supporting children's hobbies, inviting intensive communication, reprimanding without violence, and creating a comfortable atmosphere at home.
\end{abstract}

Keywords: communication, interpersonal communication, self-confidence.

\begin{abstract}
Abstrak
Komunikasi merupakan hal yang terpenting dalam kehidupan. Komunikasi merupakan interaksi antara satu orang dengan satu orang atau lebih. Penelitian ini akan memfokuskan pada komunikasi antarpribadi yang terjadi antara ibu dengan anak dalam membangun rasa percaya diri. Karakter seorang anak ditentukan oleh seorang ibu, karena adanya kedekatan seorang ibu selama berada di rumah. Waktu anak dengan ibu di rumah jauh lebih banyak daripada seorang ayah. Oleh karena itu, sifat seorang anak sepenuhnya diturunkan oleh ibu. Kasih sayang dan rasa perhatian seorang ibu sangat mempengaruhi rasa percaya diri anak. Ibu berkomunikasi pada anaknya agar anak merasa senang dan nyaman. Penelitian ini menggunakan pendekatan kualitatif. Teknik pengumpulan data dengan cara wawancara semiterstruktur pada ibu dan anak yang merupakan siswa SMA. Penelitian ini menunjukkan bahwa, kedekatan antara anak dan ibu tidak ditentukan oleh jenis kelamin. Ibu memiliki peran krusial dalam membuat anak tampil percaya diri. Caranya dengan mengingatkan anak untuk menjadi diri sendiri, mendukung hobi anak, mengajak berkomunikasi secara intensif, menegur tanpa kekerasan, serta menciptakan suasana yang nyaman di rumah.
\end{abstract}

Kata Kunci: komunikasi, komunikasi antarpribadi, percaya diri.

\section{Pendahuluan}

Komunikasi antarpribadi berpengaruh pada seorang ibu terhadap anaknya dalam membangun rasa percaya diri. Hal ini disebabkan, waktu anak dengan ibu di rumah jauh lebih banyak dibandingkan dengan ayah. Selain itu, saat anak di dalam kandungan seorang ibu, seorang anak memiliki kedekatan baik secara fisik maupun emosional. Karakter anak tidak akan terlepas dari karakter seorang ibu. 
Hubungan ibu dengan anak sangat dekat, sifat anak akan sepenuhnya diturunkan oleh seorang ibu. Perhatian, kasih sayang, dan cinta kasih yang diberikan bunda sangat mempengaruhi karakter seorang anak. Dalam komunikasi antar pribadi, terdapat kategori hubungan diadik yakni komunikasi antara dua orang yang mempunyai hubungan jelas seperti anak dan ibu, dua orang ketika wawancara, dst. Definisi hubungan dapat diperluas hingga menjadi kelompok kecil, berupa anggota keluarga maupun kelompok dari tiga atau empat orang (DeVito, 2011).

Dalam keluarga, komunikasi antar anggota keluarga menjadi hal penting. Kualitas komunikasi dengan orangtua tidak ditentukan oleh jarak dan lokasi. Misalnya, tidak semua orangtua yang berpisah dengan anaknya memiliki masalah dalam komunikasi. Seringkali justru anak yang tinggal bersama orangtua memiliki masalah dalam komunikasi. Salah satu penyebab kurangnya komunikasi adalah kemajuan teknologi canggih, sehingga masing-masing anggota keluarga sibuk dengan telepon seluler/gadget (kompas.com).

Rasa percaya diri diperlukan oleh seorang anak ataupun orangtua. Sifat percaya diri, merupakan keyakinan yang dimiliki seseorang untuk memperoleh hasil yang diinginkan (Bandura, 1977). Menurut Lauster, rasa percaya diri bukan bawaan melainkan pengalaman hidup, pendidikan, hingga meningkatkan rasa percaya diri. Terbentuk dan berkembangnya rasa percaya diri, dilalui pada proses pembelajaran dengan cara berinteraksi pada seseorang dan lingkungannya (Siska, Sudardjo dan Purnamaningsih, 2003: 67-71).

Ciri-ciri seseorang yang memiliki rasa percaya diri antara lain bersikap tenang, mampu beradaptasi pada berbagai keadaan, memiliki kemampuan untuk melaju masa depan, mampu bersosialisasi, serta pengalaman hidup yang membuat jiwanya kuat. Sedangkan, sifat kurangnya rasa percaya diri yaitu mudah cemas ketika menghadapi masalah sulit, memiliki jiwa yang lemah, latar belakang keluarga yang tidak benar, mudah putus asa, sering menyendiri dari kelompok, dan pernah trauma (Hakim, 2002). Penelitian ini ingin mengetahui komunikasi antar pribadi orangtua dalam hal ini ibu dan anak dalam membangun rasa percaya diri anak di tempat umum.

\section{Metode Penelitian}

Penelitian ini menggunakan pendekatan kualitatif. Menurut Sugiyono (2009 :15), penelitian kualitatif didasari sumber ilmu pengetahuan alam yang benar dan menolak aktivitas yang berhubungan serta digunakan untuk penelitian objek ilmiah. Strategi penelitian yang digunakan yaitu fenomenologi. Fenomenologi merupakan strategi penelitian di mana peneliti menyelidiki secara cermat pada suatu program, peristiwa, aktivitas atau sekelompok individu (Creswell, 2010:20).

Teknik wawancara yang digunakan yaitu wawancara semi terstruktur. Holloway \& Wheeler (1996) mengemukakan bahwa wawancara semi terstruktur diawali dengan masalah yang terdapat pada pedoman wawancara. Jawaban pertanyaan ini bergantung pada proses wawancara dan jawaban tiap responden sehingga peneliti dapat memperluas pertanyaan dan memutuskan sendiri masalah yang harus dimunculkan, tanpa membuang-buang waktu. Wawancara dapat bersifat panjang atau rinci, namun tidak bersifat memaksa. Pedoman wawancara berfokus pada tujuan tertentu yang diteliti, tetapi dapat diperbaiki ketika ada ide yang mucul belakangan. Hal utama yang diutamakan oleh pewawancara adalah tema penelitian tergali. 
Subjek yang akan diteliti sebagai penelitian adalah ibu dengan anak yang duduk di bangku SMA. Tempat yang akan dijadikan penelitian, rumah masingmasing dengan menggunakan. Wawancara dilakukan secara online dengan aplikasi WhatsApp. Pandemi COVID-19 membuat masing-masing individu melakukan aktivitas di dalam rumah. Wawancara dilakukan pada tiga ibu dan dan anak-anaknya yang merupakan siswa-siswi SMA. Narasumber penelitian ini yaitu Ajeng (siswi SMK Negeri 3 Bandung, kelas 1), Faikoh (siswa SMA 93 Jakarta, kelas 11), Reynaldi (siswa SMA 67 Jakarta, kelas 11). Berserta ibu ketiga narasumber tersebut yang dalam penelitian ini disebut dengan mama Ajeng, mama Faikoh dan mama Reynaldi.

\section{Hasil Temuan dan Diskusi}

Kasus COVID-19 menyebabkan masing-masing individu melakukan aktivitas di dalam rumah. Cara seorang ibu membuat anaknya tampil dalam membangun rasa percaya diri di tempat umum. Awal mulanya, seorang ibu pertama kali mengajarkan anaknya untuk membangun rasa percaya diri, bagaimana seorang ibu berkomunikasi dengan anak, dan perilaku seorang ibu ketika menghadapi anak yang berbuat salah.

Narasumber, Ajeng siswi di Bandung, merasakan percaya diri pada orang yang sudah dikenal, tetapi kurang nyaman saat bertemu dengan orang baru. Narasumber sering melontarkan perasaan, tetapi tidak diceritakan semuanya pada ibu dalam memberi saran. Ajeng merasakan kedekatan dan senang ketika berkomunikasi dengan ibu karena dukungan ibu pada hobinya. Sementara, dari hasil wawancara dengan ibu Ajeng, menunjukkan bahwa ibu meminta anaknya percaya diri dengan menjadi diri sendiri. Sifat rasa percaya diri telah diajarkan sejak sekolah dasar. Setiap hari ibu Ajeng berkomunikasi dengan anaknya. Jika ada kesalahan, ibu memarahi dan memberitahu sebab dan akibat dari perbuatan tersebut, tanpa kekerasan.

Faikoh, siswa di Jakarta, kurang percaya diri bila bertemu dengan orang baru. Tidak semua masalah diceritakan kepada ibu. Faikoh hanya menceritakan masalah sekolah sementara masalah pribadi tidak pernah diceritakan dengan ibu. Saat berkomunikasi dengan ibu, Faikoh merasa senang. Hobi seni bela diri yang ia tekuni selalu didukung oleh ibu. Bahkan ibu juga menemani saat latihan hingga pertandingan. Ibu Faikoh sendiri memberikan pujian berupa reward untuk anaknya yang tampil percaya diri. Pada usia 1 tahun, ibu Faikoh sudah mengajarkan anaknya untuk membangun rasa percaya diri. Komunikasi pun sering dilakukan. Jika Faikoh berbuat salah, ibu akan memberikan teguran bahwa apa yang dilakukan itu salah.

Reynaldi siswa di Jakarta, tampil percaya diri saat bertemu dengan orang. Narasumber tidak sering melontarkan perasaan atau meminta saran dari seorang ibu. Narasumber mengaku senang ketika berkomunikasi dengan ibu. Hobi atau kesukaan Reynaldi selalu didukung oleh ibu. Di samping itu, ada perasaan yang ditutupi oleh Reynaldi.

Penelitian ini juga menunjukkan bahwa jenis kelamin anak perempuan atau laki-laki tidak menentukan kedekatan pada seorang ibu. Dari hasil wawancara anak laki-laki dari narasumber justru paling senang berkomunikasi dengan ibu. Seluruh narasumber mengatakan bahwa masalah yang dialami pada diri sendiri tidak diceritakan secara detail kepada ibu, hanya bagian tertentu yang dirasa penting.

Sementara dari sisi orangtua, hal utama yang paling penting adalah menciptakan susasana nyaman di rumah. Anak akan merasa betah ketika berada di 
rumah, selalu ajak mereka makan bersama, berdiskusi bersama tanpa menggunakan nada suara yang keras seperti membentak-bentak.

Selain itu, seringkali seorang ibu membanggakan anaknya dengan cara yang salah. Misalnya memaksakan kehendaknya kepada anak. Ibu yang mampu membangun kepercayaan diri akan mengajarkan anak untuk mengikuti keinginan diri sendiri. Seorang anak akan sukses dan berhasil, apabila memilih sesuai dengan keinginannya.

Penelitian ini juga melihat bahwa ibu yang berhasil membangun kepercayaan diri anak akan menghindari perbuatan yang mempermalukan anak di depan umum. Hal ini akan membuat anak kurang percaya diri dalam bersosialisasi karena anak menilai dirinya mengalami banyak kekurangan. Ini menyebaban anak memilih untuk menyendiri. Orang yang rendah diri merupakan orang yang kurang percaya diri.

\section{Simpulan}

Penelitian ini menyimpulkan bahwa jenis kelamin tidak menentukan kedekatan seorang anak pada ibu. Meski dekat secara fisik dan perasaan, seorang anak tidak serta merta menceritakan masalahnya secara detail kepada ibu. Anak hanya menceritakan bagian tertentu yang dianggap penting.

Seorang ibu harus memperhatikan ucapan yang disampaikan kepada anaknya. Hal ini karena ucapan tersebut bisa membekas pada anak. Ibu harus mampu menyeimbangkan situasi dan kondisi, saat di rumah dan lingkungan kerja. Ibu berperan menentukan keberhasilan bahkan kegagalan seorang anak.

Hal utama yang paling penting untuk anak adalah ibu menciptakan suasana nyaman di rumah. Anak akan merasa betah ketika berada di rumah hanya melalui ajakan makan bersama, berdiskusi bersama tanpa menggunakan nada suara yang keras seperti membentak-bentak, mendukung hobi anak, tidak memaksakan kehendak kepada anak dan tidak mempermalukan anak. Orangtua sangat mempengaruhi komunikasi antarpribadi antara orangtua dan anak usia remaja dalam pembentukan rasa percaya diri pada anak.

\section{Ucapan Terima Kasih}

Terima kasih pada bapak/ ibu dosen Universitas Tarumanagara, keluarga, teman-teman yang selalu memberikan saran pada penulis, ibu dan siswa-siswi SMA, yang telah meluangkan waktunya menjadi narasumber penelitian ini.

\section{Daftar Pustaka}

Devito, Joseph. A. 2011. Komunikasi antarmanusia (ed.5). Tangerang: Karisma Publishing Group. hlm. 252-253

Hakim, T. 2002. Mengatasi Rasa Tidak Percaya Diri. Jakarta: Purwaswara https://lifestyle.kompas.com/read/2014/03/20/1642338/Apa.Efeknya.jika.Orangtua.Ja rang.Berkomunikasi.dengan.Anak

Siska, Sudardjo, Purnamaningsih, Esti Hayu. 2003. Kepercayaan diri dan Kecemasan Komunikasi Interpersonal Pada Mahasiswa. Jurnal Psikologi. No 2. 67-71.

Sugiyono. 2009. Metode Penelitian Kualitatif, Kualitatif dan R\&D. Bandung: Alfabeta. 